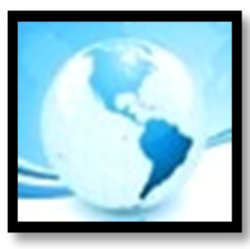

MALAYSIAN ONLINE JOURNAL OF

EDUCATIONAL MANAGEMENT

(MOJEM)

April 2018, VOLUME 6, ISSUE 2, 22 - 40

E-ISSN NO: $2289-4489$

https://doi.org/10.22452/mojem.vol6no2.2

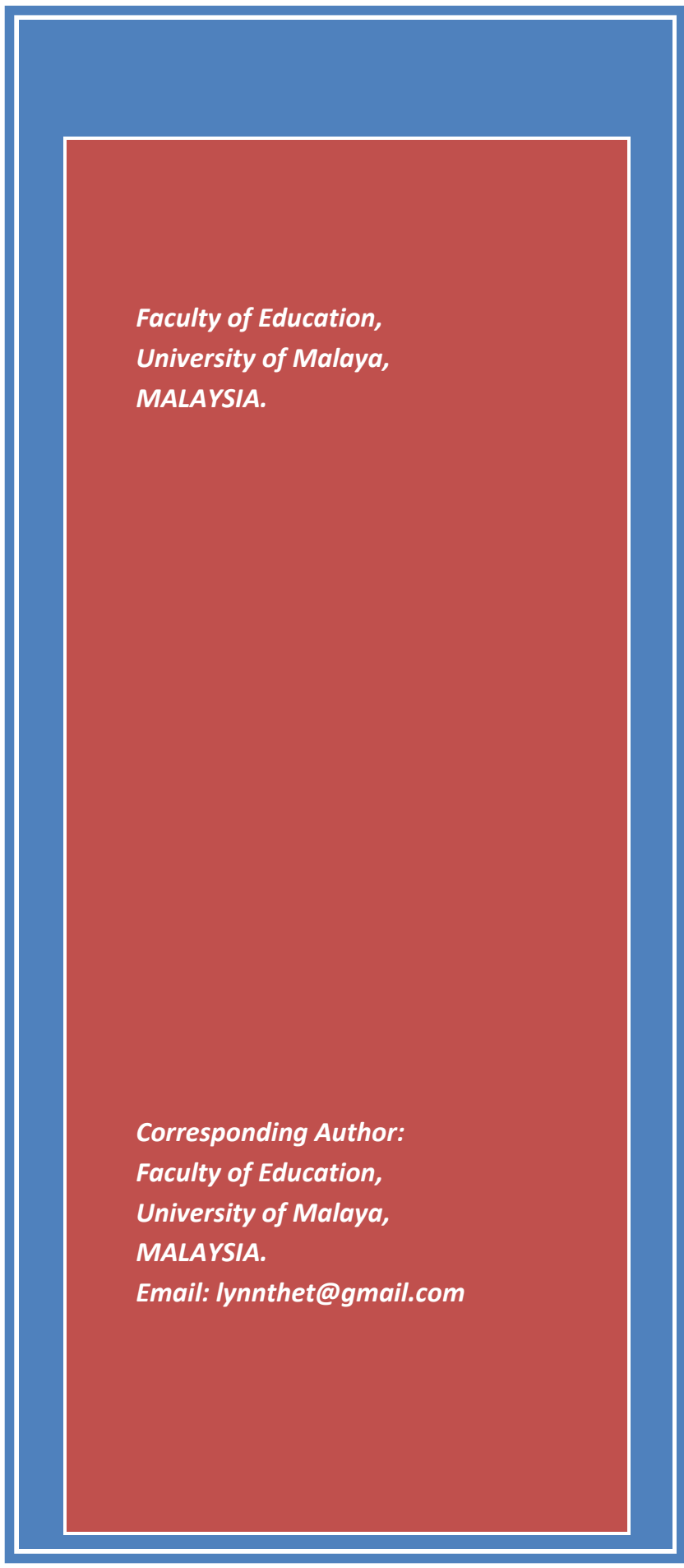

\title{
LOCALIZATION OF THE GLOBAL NURSING PROCESS IN MALAYSIAN CONTEXT: STUDENT NURSES PERSPECTIVES
}

Lynn Lynn Thet (PhD), Ahmad Zabidi Abdul Razak (PhD), Shahrir Jamaluddin (PhD) \& Simin Ghavifekr (PhD)

Faculty of Education,

University of Malaya,

MALAYSIA.

Corresponding Author:

Faculty of Education,

University of Malaya,

MALAYSIA.

Email: Iynnthet@gmail.com 


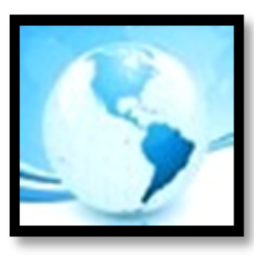

\section{MALAYSIAN ONLINE JOURNAL OF EDUCATIONAL MANAGEMENT (MOJEM)}

\section{INTRODUCTION}

Nursing care has evolved over the years with the scope of disease focused medical model and task-oriented functional nursing. However, its focus moves to scientific, systematic, holistic, and individualized professional approach through applying the nursing process as a model/framework in the daily nursing care activities. The nursing process, a globally accepted professional nursing framework was first established during the 1950s-1960s. Since its evolution, the dissemination and innovation of nursing process became worldwide. Uys and Habermann (2005) stated that the nursing process represents a global concept that is being taught, discussed and implemented around the world. There are various successful and unsuccessful stories from the different countries that have implemented the nursing process application as a professional framework in their countries' nursing education and practice.

The concept of nursing process has been transported all over the world after approximately 25 years later of its evolution. It has also been adopted by important global organizations such as World Health Organization (WHO) and International Council of Nurses (ICN). The national governments and nursing organizations based legal prescription of quality nursing on nursing process are evident in countries such as Sweden, Germany, UK, South Africa, State Practice Act in USA, the American Nurses Association (ANA) and the United Kingdom Central Council for Nursing, Midwifery and Health Visitors (UKCC). At the end of the $20^{\text {th }}$ century, Czech Republic recently followed this trend of implementing nursing process (Mellanova, 2005).

According to Uys and Habermann (2005), the "blind spots" on the international map in regard to application of nursing process are quick to adopt this new process as soon as they join the global nursing discourse. In a nutshell, evaluating the concept of nursing process through looking at the good quality in the nursing work seems to promote a successful image; however, when taking into account the variety of theoretical and professional evaluation that are conducted in these various countries, it shows a different end result altogether. Therefore, the questions that rises from this issue are: "What makes the ideas and concepts in these nursing process that have not yet been proved with evidence whilst having a history of doubtful utilization in the practical field to be disseminated globally?" On what type of structure and processes are innovation in nursing process based of, and how do they evolve in practice?

With respect to the current American and Canadian's nursing practice standards, it stresses on the application of nursing process proficiently and participation in professional activities that contribute to the development of knowledge about application of the nursing process permanently (Alfaro-Lefevre, 2006, cited by Pokorski et al., 2009). Vaz et al. (2002) also stated that there is a demand to practice the nursing process practically in all health institutions, which means not only in hospitals but also in the community with the concept of community as a whole (cited by Pokorski et al., 2009). However, not all steps of nursing process are systematically implemented in practice. Similarly, Davis et al. (1994), Ehrenberg et al. (1996), Cunha and Barros (2005) and Lima and Kurcgant (2006), revealed that there had been difficulties to establish and apply the nursing process in Brazil and other countries during last years (cited by Pokorski et al., 2009).

The nursing process was initially introduced as a mandate in educational and professional in providing nurse care rather than a component in a nursing organization (Mason and Attree, 1997). It has been essential to nursing practice and are used as a problem-solving activity whilst thinking about a plan of care in their daily nursing practice. Nursing process activities involves creating nursing care plan that enhances the student nurses to practice critical thinking and decision-making skills in their learning contexts (Yildirim \& Ozkahraman, 2011). Hagos, Alemseged, Balcha, Berhe and Aregay (2014) stated that nursing process is considered as a proper method to clarify the essence of nursing, support creativity and critical thinking, and allow problem solving. 


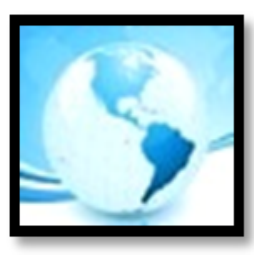

\section{MALAYSIAN ONLINE JOURNAL OF EDUCATIONAL MANAGEMENT (MOJEM)}

Seaback (2006) believed that the nursing process is a scientific, as well as a philosophical based model. In addition, Willis (2012) stated that for a process of professional growth and development, the nursing process is a tool used to educate and assess the students and promote critical thinking and evidence-based knowledge for the experienced nurse. In addition, nursing as a profession, must be exercised a reliable, high level of critical thought together with critical actions (Yildirim \& Ozkahraman, 2011). Applying critical thoughts within the nursing process is an important construct in the nursing practice as a professional practice. The nursing process however, has proved to be a means of standardizing nursing care and in maintaining professional autonomy. As a result, many nurses needed to understand the process fully and put it into practice (Afolayan et al., 2013).

In Malaysia, the Nursing Task Force Committee under the Department of Higher Education, Ministry of Education (MOE) has formulated eleven agendas in order to fulfil the Nursing Vision 2020 which is based on the Vision 2020 of MOE. Amongst the agendas, the first, second and fourth agenda are focused and intended to change Malaysian nursing context towards a professional standard. Therefore, commencing from 2010, the Department of Higher Education implemented the nursing process as a professional model to produce professionally prepared nursing graduates in Malaysia by 2016. The Department of Higher Education intends that all employers of new nursing graduates to possess at minimum, four basic nursing competencies which are: (critical thinking \& problem solving, knowledge-based practice, clinical competence \& accountability and ethical practice) all of which are encompassed in the Nursing Process. It means that the nations' professional nursing approach are upgraded from the previously practiced functional task-orientated nursing approach to the new globally accepted nursing model, the Nursing Process. Therefore, strategies were established to implement nursing process in order to produce professionally prepared nursing graduates (MOHE, 2010).

Based on the success and recommendations of previous studies, it is important to evaluate the implementation of nursing process in Malaysian nursing education context in terms of investigating the factors influencing and mediating in the implementation process of nursing process application. Therefore, the main purpose of this study is to identify the factors that influence and mediate the implementation of nursing process application in the Malaysian nursing education. More specifically this research aims:

I. To identify significant predictors among demographic characteristics (gender and mode of study), knowledge, attitude and impression towards supporting factors in the practice of student nurses.

II. To investigate any mediating effect of student nurses' attitude towards nursing process on the relationship between the student nurses' knowledge and practice.

III. To investigate any mediating effect of student nurses' impression towards supporting factors on the relationship between the student nurses' knowledge and practice.

\section{THEORETICAL FOUNDATION}

According to National Institute for Health and Clinical Excellence (NICE) (2007), changing a process can take long time, especially in a clinical guideline. It can take up to three years to be fully implemented. It is important to consider the scale of change that can be achieved realistically, because even small changes can get a positive impact if the change engages an action which is repeated often. In any kind of change in any situation, there are certain factors that help to foster an environment to be either be conducive or impede the change process. To develop a successful strategy for change, there must be a need in understanding the types of barriers that are commonly faced in health care area. 


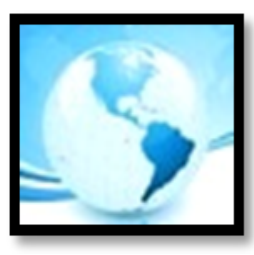

\section{MALAYSIAN ONLINE JOURNAL OF EDUCATIONAL MANAGEMENT (MOJEM)}

There are five types of barriers, namely, awareness and knowledge, motivation, acceptance and beliefs, skills, and practicability (NICE, 2007). Awareness and knowledge are the vital first step in enabling change to occur. The evidence shows that the health care professionals are often not aware of the latest evidence-based guidance and showcased a lack of familiarity with it. Meanwhile, motivation is an essential part of nearly everything to carry out successfully. There are external factors such as providing incentives or penalties as a part of regulatory checks and internal factors such as self-motivation derive and desire to improve of each individual which influence the motivation and change behaviour.

In addition, (NICE, 2007) explained that a person's personal beliefs and attitudes impact one another significantly. Perception on the benefits of any proposed change versus the costs, both practical and financial can be important. A person's belief in their own affords to adopt a new behaviour also has an impact on whether a change can be implemented successfully or not. The individuals need to know what are needed for change to happen and how best to competently carry out the change while implementing the change into action. The health care professionals may need training, the time to learn, support from peers or mentoring while engaging the new skills and practice. The individual's ability, interpersonal skills and coping strategies will also influence on how easy or difficult for those individuals to learn new skills. The barriers in practicability involve a lack of resources or personnel or difficulties in establishing in delivery of service and difficulty in maintaining change in long term (sustainability).

When looking back to the implementation of NPM in nursing education and practice agenda, it was a new push in innovation of nursing towards the professional nursing. Many studies were conducted to identify what factors are influencing the implementation of nursing process. For example, Salcedo's (2004) study mentioned that education and training are important. Walton (1986) and De La Cuesta's (1983) study pointed out that deficiencies in nursing education were a barrier, Farmer (1986) specifically pointed out that lack of critical skills in nursing education in the past is one of the causes in facing difficulties. In addition, Martin and et al. (1997), Serrano et al. (1994), Miller et al. (1987) and, Specht and Drey (1987) highlighted that providing knowledge on the nursing process and the skills to carry out it in their practice, Serrano et al. (1994), meanwhile concentrated on the importance of education programmes and taking into account upon the attitude of nurses, DHSS 1986 report mentioned on the importance of understanding and favour of managers, staff nurses and other health professionals concerning the introduction of the nursing process (cited by Salcedo, 2004).

Additionally, Aseratie, Murugan and Molla's (2014) study highlighted the influence of organizational factors, level of knowledge and skill which are highly influencing the implementation process. Moreover, Foroozan and Tahereh (2011) study focused on the personal-managerial factor which includes awareness, attitude and skill of the person involved human resources, reinforcement and punishment, suitable tools and conditions, cooperation, and supervision at the managerial levels. Their study revealed that the impressions of nurses upon the implementation of nursing process to be varied and complex.

Therefore, it can be concluded that the education and practical changing context of nursing education and practice on the implementation of nursing process is influenced by various factors such as the level of knowledge, which depend on the quantity and quality of implementation process of NPM application, the attitude towards NPM and its implementation process, and the complexity and practicality of nursing process itself. Furthermore, the practice factor is influenced by many factors such as the organizational factors, personal and managerial factors, the education status, the socio-demographic status, the willingness and the attitude towards change, and the professional factor. 
In addition, any change process produces a certain amount of stress, and the success depends on the ability to overcome the barriers mentioned above. Therefore, the researchers conducted this study to identify the factors influencing on the nursing process. Whether the student nurses' demographic characteristics (gender and mode of study), knowledge about nursing process, attitude towards nursing process and impression towards supporting factors are influencing upon the practice of nursing process or not. In addition, the researchers seek to identify whether the attitude and supporting factors are mediating in a relationship between knowledge and practice of nursing process. Figure 1 illustrates the nursing process as a globally practiced professional development model that the Department of Higher Education adopted to produce professionally prepared nursing graduates by the year 2016. It is composed of five interrelated steps namely Assessment, Diagnosis, Planning, Implementation and Evaluation.

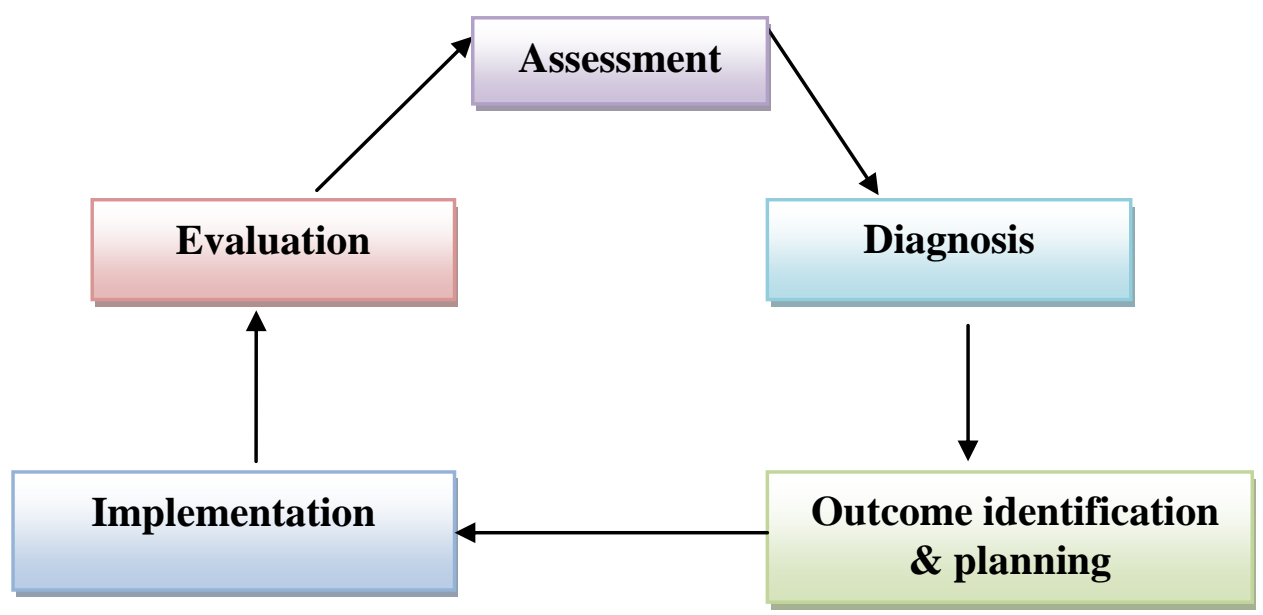

Figure1. Global Nursing Professional Development Model

\section{METHOD}

This study investigated the factors that are influencing the implementation of nursing process application, and the factors that mediate while translating knowledge of nursing process theory to practice among student nurses. The designs of this research comprises the procedure that guide in collecting, analysing, interpreting and reporting data in research studies (Creswell, 2012). In this study, a descriptive-exploratory design and cross-sectional survey were conducted in five universities in East and West Malaysia.

\section{Sampling}

A randomly selected sampling technique was used to collect data from a total of 468 student nurses. All student nurses who were enrolled from the year 2010 were included as the nursing process in the Malaysian Nursing Education were implemented in the year 2010. All student nurses willingly participated in this study.

\section{Instrumentation}

An adapted structured questionnaire composed of five sessions was used to collect data for this study. The questionnaire consisted of various sections including: 
I. Demographic profile (age, gender, mode of study, current semester)

II. Concepts of nursing process to evaluate their level of knowledge about it

III. Their impression towards the application of nursing process in their practical setting

IV. Their attitude towards nursing process and its application

V. Their impression towards the factors that support in application of nursing process.

The items for evaluating the knowledge of nursing process were through choosing correct and incorrect answers. A five-point Likert scale was used in the questions which are evaluating their attitude, practice and impression towards supporting factors in application of nursing process.

There are 21 questions given in order to assess the student nurses' level of knowledge which are based on the basic concepts concerning the steps of nursing process. These questions are adapted from NCLEX (National Council Licensure Examination) website. There are 20 items to questioned in order to assess the student nurses' attitude; which are adapted from Hagos et al. (2014) study which include the attitude towards the aims and application of nursing process, practicality and practicability of nursing process, current nursing documentation/record system, the time constraint in application of nursing process, and the climate of the clinical learning environment. In addition, there are 9 items asked in order to assess the student nurses' impression towards supporting factors which are focusing on hospital administration support, the resources available, the time available to apply, the nurse patient ratio, motivation, effective monitoring and evaluation system, supportive hospital learning environment, staff nurses' application of nursing process and the student nurses' confidence to apply nursing process in real practical settings.

\section{Reliability and Validity}

A pilot study was conducted in a public university from East Malaysia which is excluded in the actual study. The researchers conducted the pilot study with $10 \%$ of study population from this public university. The structured questionnaire tested for reliability and Cronbach Alpha value shows good reliability index (alpha coefficient .8). In addition, the researcher conducted construct validity through Confirmatory Factor Analysis (CFA) by using SPSS 22.0 and AMOS 23.0 and the result revealed were significant.

\section{Administrative and Ethical Consideration}

Legal permissions were obtained from the Faculty of Medicine, Faculty/Department of Nursing, and Research and Innovation Committee of respective universities. As an ethical consideration, the researcher composed the cover letter together with informed consent in the questionnaire, explaining the study's details alongside ensuring anonymity and confidentiality of the information given by participants. The participant was also requested to sign a consent form which serves as proof of them being voluntary with this study.

\section{Data Collection and Analysis}

The data were collected from five universities (four public and one private) from East and West Malaysia through the use of administering a structured questionnaire. The data collected were then statistically analysed using SPSS version 22.0. The researchers conducted multiple regression analysis to identify the factors influencing, and the mediation analysis was carried out by using Sobel Test mediation analysis to identify whether the attitude and supporting factors are mediating in a relationship between knowledge and practice. 


\section{RESULTS}

A total of 468 student nurses actively participated in the survey. The majority of them were female (85.3\%) with the age group category of $20-29$ years (77.1\%) leading many of them. Moreover, majority of respondents were Bachelor of Nursing Science (59.4\%) and Diploma in Nursing (34.2\%). Most of them were still studying and are in the range of the $1^{\text {st }}$ to $8^{\text {th }}$ semester $(94.6 \%)$.

The researchers investigated the student nurses' demographic characteristics (gender and mode of study), knowledge, attitude and impression towards supporting factors as predictors in application of nursing process by multiple regression analysis. Before proceeding the multiple regression analysis, the researchers assessed whether the assumptions to conduct multiple regression is met or not, such as the normality of the data in terms of skewness and kurtosis, residuals, and multicollinearity among the variables.

The values greater or lesser than 1.9 are sufficient to establish normality of the data in small samples (less than 50); however, in large sample which means 200 or more, this criterion should be changed to \pm 2.58 (Field 2009 , cited by Ghasemi \& Zahediasl, 2012).

All the variables which are gender, mode of study, knowledge, attitude, practice and supporting factors are normally distributed respectively; the student nurses' gender with skewness of -1.995 (SE $=.113$ ) and kurtosis of 1.990 (SE = .225); student nurses' mode of study with skewness of .353 (SE =.113) and kurtosis of .423 (SE = .225); student nurses' knowledge with skewness of -.531 (SE = .113) and kurtosis of .578 (SE = .225); the attitude of student nurses with skewness of .656 (SE = .113) and kurtosis of .529 (SE = .225); student nurses' impression towards their practice with skewness of .537 (SE = .113) and kurtosis of $.377(\mathrm{SE}=.225)$; and the impression of student nurses towards supporting factor with skewness of -.002 (SE =.113) and kurtosis of .385 (SE =.225). The following Table 1 presents the detail description of the findings for normality check.

Table 1

Check for Normality: Skewness and Kurtosis ( $n=468)$

\begin{tabular}{lllllll}
\hline & \multicolumn{7}{c}{$\begin{array}{l}\text { Mode of } \\
\text { Gender }\end{array}$} & $\begin{array}{l}\text { Ktudy } \\
\text { N }\end{array}$ & Knowledge & Attitude & Practice & Supporting \\
\hline$\quad$ Valid & 468 & 468 & 468 & 468 & 468 & 468 \\
\multicolumn{1}{c}{ Missing } & 0 & 0 & 0 & 0 & 0 & 0 \\
Skewness & -1.995 & .353 & -.531 & .656 & .537 & -.002 \\
Std. Error of Skewness & .113 & .113 & .113 & .113 & .113 & .113 \\
Kurtosis & 1.990 & .423 & .578 & .529 & .377 & .385 \\
Std. Error of Kurtosis & .225 & .225 & .225 & .225 & .225 & .225 \\
\hline
\end{tabular}

Referring to the reference index of Dart (2013), the standardized residuals are within 3.29 and -3.29 . The data contained no outliers in this study (Std. Residual Min $=-2.869$, Std. Residual Max $=2.979$ ) which are within the standardized residual values respectively (see Table 2). 
Table 2

Residual check findings ( $n=468$ )

Residuals Statistics

\begin{tabular}{llllll}
\hline & Minimum & Maximum & Mean & Std. Deviation & N \\
\hline Predicted Value & 52.54 & 69.93 & 60.43 & 2.616 & 468 \\
Residual & -16.311 & 16.939 & .000 & 5.655 & 468 \\
Std. Predicted Value & -3.016 & 3.629 & .000 & 1.000 & 468 \\
Std. Residual & -2.869 & 2.979 & .000 & .995 & 468 \\
\hline
\end{tabular}

Note: a. Dependent Variable: Practice of students

Concerning collinearity, the data met the assumption which means there is no multicollinearity among the variables (Dart, 2013). The VIF value is less than 10 and the tolerance is less than 0.1; (gender of student, Tolerance $=.99, \mathrm{VIF}=1.01) ;($ mode of study, Tolerance $=.81, \mathrm{VIF}=1.2) ;($ knowledge score, Tolerance $=.87, \mathrm{VIF}=1.2)$; (attitude score, Tolerance $=.99, \mathrm{VIF}=1.01$ ); and (supporting factor score, Tolerance $=.85, \mathrm{VIF}=1.2$ ) respectively (see Table 3).

Table 3

The findings of Multicollinearity Check $(n=468)$

Collinearity Diagnostics

\begin{tabular}{|c|c|c|c|c|c|c|c|c|c|}
\hline \multirow[b]{2}{*}{$\begin{array}{l}\text { Mo } \\
\text { del }\end{array}$} & \multirow[b]{2}{*}{$\begin{array}{l}\text { Dimensi } \\
\text { on }\end{array}$} & \multirow[b]{2}{*}{$\begin{array}{l}\text { i Eigenva } \\
\text { ue }\end{array}$} & \multirow[b]{2}{*}{$\begin{array}{l}\text { Condition } \\
\text { Index }\end{array}$} & \multicolumn{6}{|c|}{ Variance Proportions } \\
\hline & & & & $\begin{array}{l}\text { Const } \\
\text { ant) }\end{array}$ & $\begin{array}{l}\text { Gender of } \\
\text { students }\end{array}$ & $\begin{array}{l}\text { Mode of } \\
\text { study }\end{array}$ & $\begin{array}{l}\text { Knowledge } \\
\text { students }\end{array}$ & $\begin{array}{l}\text { f Attitude of } \\
\text { students }\end{array}$ & $\begin{array}{l}\text { Supporting } \\
\text { factors }\end{array}$ \\
\hline \multirow[t]{6}{*}{1} & 1 & 5.826 & 1.000 & .00 & .00 & .00 & .00 & .00 & .00 \\
\hline & 2 & .096 & 7.804 & .00 & .02 & .66 & .00 & .00 & .02 \\
\hline & 3 & .037 & 12.468 & .00 & .25 & .14 & .67 & .00 & .00 \\
\hline & 4 & .029 & 14.119 & .00 & .61 & .09 & .17 & .01 & .11 \\
\hline & 5 & .009 & 25.562 & .02 & .04 & .07 & .05 & .34 & .65 \\
\hline & 6 & .002 & 50.971 & .98 & .08 & .03 & .10 & .64 & .22 \\
\hline
\end{tabular}

Note: a. Dependent Variable: Practice of students

According to Dart (2013), Durbin-Watson values (independent error) met the assumption of independent errors with Durbin-Watson value $=1.7$ (see Table 4).

Table 4

The findings of Independent Error $(n=468)$

Model Summary

\begin{tabular}{llllll} 
Model & $\mathbf{R}$ & R Square & Adjusted R Square & Std. Error of the Estimate & Durbin-Watson \\
\hline 1 & $.420^{\mathrm{a}}$ & .176 & .167 & 5.685 & 1.707
\end{tabular}

Note: a. Predictors: (Constant), Supporting factors, Attitude of students, Gender of students, Knowledge of students, Mode of study, b. Dependent Variable: Practice of students 


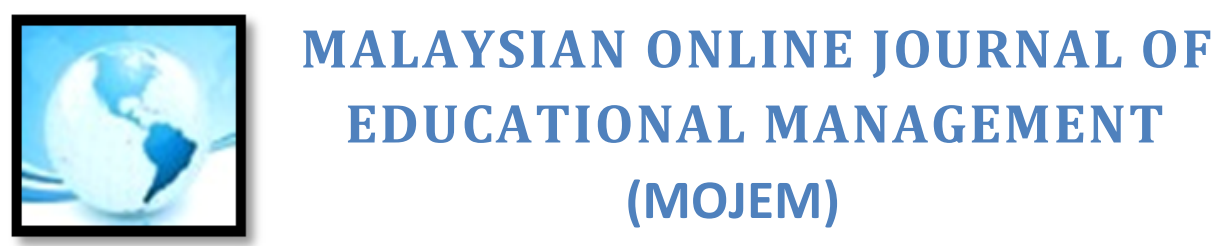

Then, a multiple regression was conducted to see if the different gender and mode of study, level of knowledge, attitude and impression towards the factors that support application of NPM predicted upon the application of NPM in their practice. The findings are shown in the following tables 5 and 6.

Table 5

The Findings of Multiple Regression Analysis: ANOVA ( $n=468)$

ANOVA $^{a}$

\begin{tabular}{lllllll}
\hline Model & & Sum of Squares & df & Mean Square & $\mathbf{F}$ & Sig. \\
\hline 1 & Regression & 3195.966 & 5 & 639.193 & 19.775 & $.000^{6}$ \\
& Residual & 14933.630 & 462 & 32.324 & & \\
& Total & 18129.597 & 467 & & &
\end{tabular}

Note: a. Dependent Variable: Practice of students, b. Predictors: (Constant), Supporting factors, Attitude of students, Gender of students, Knowledge of students, Mode of study

Table 6

The Model Summary of Multiple Regression Analysis ( $N=468)$

Model Summary

\begin{tabular}{|c|c|c|c|c|c|c|c|c|c|c|}
\hline \multirow[b]{2}{*}{$\begin{array}{l}\text { Mo } \\
\text { del }\end{array}$} & \multirow[b]{2}{*}{$\mathbf{R}$} & \multirow[b]{2}{*}{ R Square } & \multirow[b]{2}{*}{$\begin{array}{l}\text { Adjusted R } \\
\text { Square }\end{array}$} & \multirow{2}{*}{\multicolumn{2}{|c|}{$\begin{array}{l}\text { Change St } \\
\text { Std. Error of R Square } \\
\text { the EstimateChange }\end{array}$}} & \multirow{3}{*}{$\begin{array}{l}\text { F Change } \\
19.775\end{array}$} & \multirow{3}{*}{$\begin{array}{l}\text { df1 } \\
5\end{array}$} & \multirow{3}{*}{$\frac{d f 2}{462}$} & \multirow[b]{2}{*}{$\begin{array}{l}\text { Sig. F } \\
\text { Change }\end{array}$} & \multirow[b]{2}{*}{$\begin{array}{l}\text { Durbin- } \\
\text { Watson }\end{array}$} \\
\hline & & & & & & & & & & \\
\hline$\overline{1}$ & $.420^{a}$ & .176 & .167 & 5.685 & .176 & & & & .000 & 1.707 \\
\hline
\end{tabular}

a. Predictors: (Constant), Supporting factors, Attitude of students, Gender of students, Knowledge of students, Mode of study

b. Dependent Variable: Practice of students

Using the enter method, it was found that the student nurses' gender and mode of study, level of knowledge, their attitude towards NPM, its application and implementation process and their impression towards supporting factors produced a significant amount of the variance in practicing $\operatorname{NPM}\left(F(5,462)=19.775, p<.05, \mathrm{R}^{2}=.18\right.$, $\left.\mathrm{R}_{\text {Adjusted }}^{2}=.17\right)$.

Table 7

The Findings of Multiple Regression Analysis ( $n=468$ )

Coefficients

\begin{tabular}{|c|c|c|c|c|c|c|c|}
\hline \multirow[b]{2}{*}{ Model } & \multicolumn{2}{|c|}{$\begin{array}{l}\text { Unstandardized } \\
\text { Coefficients }\end{array}$} & \multirow{3}{*}{$\begin{array}{l}\text { Standardized } \\
\text { Coefficients } \\
\text { Beta }\end{array}$} & \multirow{3}{*}{$\frac{\mathbf{t}}{5.439}$} & \multirow{3}{*}{$\frac{\text { Sig. }}{.000}$} & \multicolumn{2}{|l|}{$\begin{array}{l}\text { Collinearity } \\
\text { Statistics }\end{array}$} \\
\hline & B & Std. Error & & & & Tolerance & VIF \\
\hline (Constant) & 25.875 & 4.758 & & & & & \\
\hline Gender of students & .186 & .745 & .011 & .249 & .803 & .989 & 1.011 \\
\hline Mode of study & .721 & .491 & .069 & 1.468 & .143 & .814 & 1.228 \\
\hline Knowledge of students & .140 & .039 & .163 & 3.585 & .000 & .866 & 1.155 \\
\hline Attitude of students & .113 & .050 & .095 & 2.241 & .026 & .989 & 1.011 \\
\hline
\end{tabular}




\begin{tabular}{lllllllll} 
Supporting factors & .632 & .068 & .428 & 9.319 & .000 & .845 & 1.184 \\
\hline
\end{tabular}

Note: a. Dependent Variable: Practice of students

The analysis reveals that the different gender did not significantly predict the practice of nursing process (Beta $=$ $.01, \mathrm{t}(19)=.25, p>.05)$ and mode of study also did not significantly predict the student nurses' practice of nursing process $($ Beta $=.07, \mathrm{t}(19)=1.47, p>.05)$. However, the knowledge $($ Beta $=.16, \mathrm{t}(19)=3.59, p<.05)$, the attitude $($ Beta $=.10, \mathrm{t}(19)=2.24, p<.05)$ and the impression towards supporting factors $($ Beta $=.43, \mathrm{t}(19)=9.32, p<.05)$ significantly predict the student nurses' practice of nursing process. It indicates that the student nurses' extent of knowledge, attitude towards nursing process, its application and implementation process, and their impression towards supporting factors to practice the nursing process are influencing their application of nursing process in the practical settings.

\section{Mediation Analysis}

According to Preacher and Leonardelli (2010-2016), mediation can occurr when (1) the IV significantly affects the mediator, (2) the IV significantly affects the DV in the absence of the mediator, (3) the mediator has a significant unique effect on the DV, and (4) the effect of the IV on the DV shrinks upon the addition of the mediator to the model. These criteria can be used to informally judge whether or not mediation is occurring. In this study, the researchers investigated the following questions;

- Is the attitude of student nurses upon NPM, its application and implementation process as a mediating variable in the relationship between knowledge and practice?

$\mathrm{X}(\mathrm{IV}) \quad$ Extent of Knowledge

$\mathrm{M}$ (Mediator) = Attitude towards nursing process, its application and implementation process

$\mathrm{Y}(\mathrm{DV}) \quad=$ Practice of nursing process

- Is the impression of student nurses upon supporting factors as a mediating variable in the relationship between knowledge and practice?

$\mathrm{X}(\mathrm{IV}) \quad$ Extent of Knowledge

$\mathrm{M}$ (Mediator) = Impression towards supporting factors in application of nursing process

$\mathrm{Y}(\mathrm{DV})=$ Practice of nursing process

In order to test whether these three conditions are met to precede mediation analysis, the researcher conducted the correlation coefficients for the relationship between these variables; knowledge, attitude and practice (attitude as a mediator in the relationship between knowledge to practice) and the findings are as follow:

Table 8

The findings of Pearson correlation coefficients among variables $(n=468)$

Correlations

\begin{tabular}{lllll}
\hline & & Knowledge & Attitude & Practice \\
\hline Knowledge of students & Pearson Correlation & 1 & -.085 & .067 \\
& Sig. (2-tailed) & & .065 & .145 \\
& $\mathrm{~N}$ & 468 & 468 & 468 \\
Attitude of students & Pearson Correlation & -.085 & 1 & $.109 *$ \\
& Sig. (2-tailed) & .065 & & .019
\end{tabular}




\begin{tabular}{lllll} 
& N & 468 & 468 & 468 \\
Practice of students & Pearson Correlation & .067 & $.109^{*}$ & 1 \\
& Sig. (2-tailed) & .145 & .019 & \\
& N & 468 & 468 & 468 \\
\hline
\end{tabular}

*. Correlation is significant at the 0.05 level (2-tailed).

According to the correlation coefficients mentioned in the above table, the correlation coefficients between independent (knowledge) to dependent variable (practice), independent variable (knowledge) to mediator (attitude) are not significant; however, the mediator (attitude) to the dependent variable (practice) is significant. These results indicate that each of these condition are not necessary to test for the possible role of attitude as a mediator has not been met at the bivariate level. Then, the researcher conducted the correlation coefficients for the relationship between three variables; knowledge, impression towards supporting factors and practice (impression towards supporting factors as a mediator in the relationship between knowledge to practice) and the findings are as follow.

Table 9

The findings of Pearson correlation coefficients among variables $(n=468)$

Correlations

\begin{tabular}{lllll}
\hline & & Knowledge & Supporting & Practice \\
\hline Knowledge of students & Pearson Correlation & 1 & $-.255^{* *}$ & .067 \\
& Sig. (2-tailed) & & .000 & .145 \\
& $\mathrm{~N}$ & 468 & 468 & 468 \\
\multirow{3}{*}{ Supporting factors } & Pearson Correlation & $-.255^{* *}$ & 1 & $.368^{* *}$ \\
& Sig. (2-tailed) & .000 & & .000 \\
Practice of students & $\mathrm{N}$ & 468 & 468 & 468 \\
& Pearson Correlation & .067 & $.368^{* *}$ & 1 \\
& Sig. (2-tailed) & .145 & .000 & \\
& $\mathrm{~N}$ & 468 & 468 & 468 \\
\hline
\end{tabular}

**. Correlation is significant at the 0.01 level (2-tailed).

According to the correlation coefficients mentioned in the above table, the correlation coefficients between independent (knowledge) to dependent variable (practice) is not significant. However, the independent variable (knowledge) to mediator (impression towards supporting factors in implementation of nursing process application), and the mediator (impression towards supporting factors in implementation of nursing process application) to the dependent variable (practice) are significant. These results indicate that, at the bivariate level, each of the conditions necessary to test for the possible role of impression towards supporting factor as a mediator has been met. The mediation analysis performed referring to a webpage developed by Preacher and Leonardelli (2010-2016). The path diagram for impression towards supporting factors as mediator is as follow: 

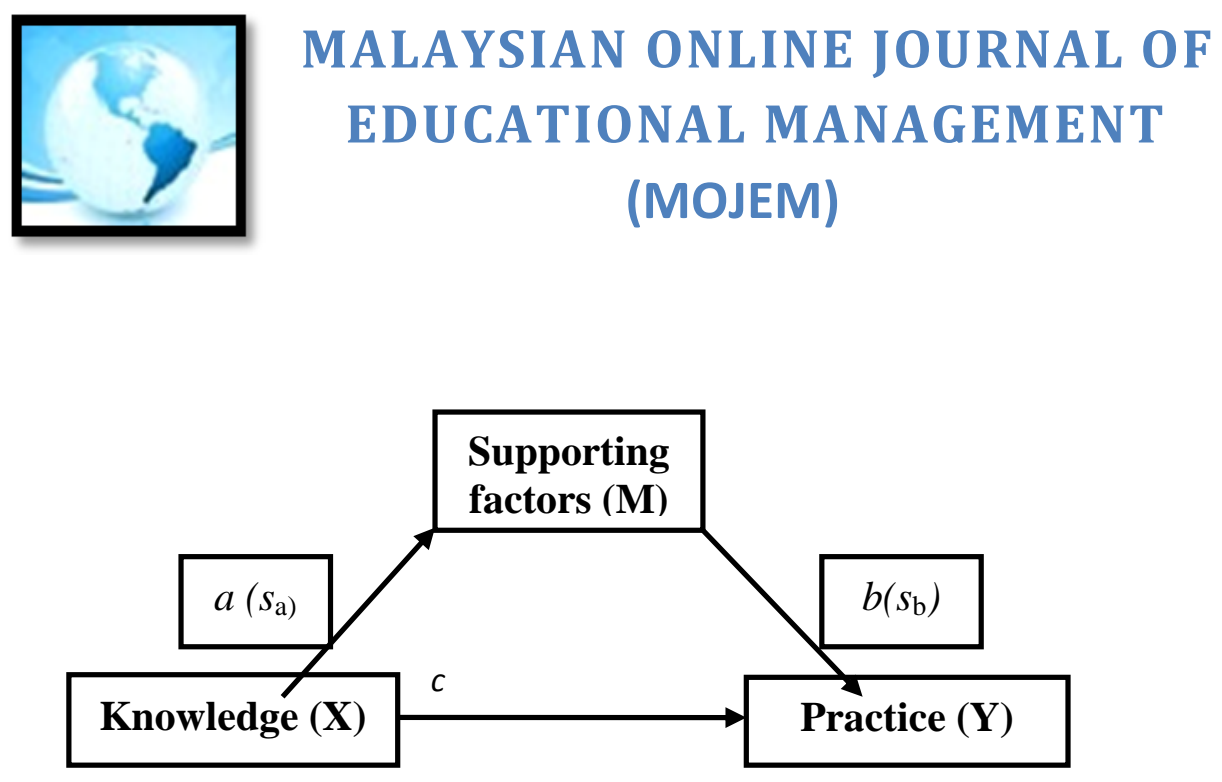

Figure 1. The path diagram of supporting factors as mediator in a relationship between knowledge and practice of student nurses

In a mediation analysis, $a, b$, and $c$ are path coefficients. To conduct mediation, the needed numbers, include " $a$ " is raw unstandardized regression coefficient for the association between IV and mediator; $s_{a}$ is standard error of $a ; b$ is raw coefficient for the association between the mediator and the DV (when the IV also a predictor of the DV), $s_{\mathrm{b}}$ is standard error of $b$. The researchers performed regression analysis on the association between knowledge and impression towards supporting factors (knowledge as independent variable and impression towards supporting factors as dependent variable) to get raw unstandardized regression coefficient. Then, the researcher performed regression analysis with knowledge and attitude predict practice. The following table presents the findings of regression analysis.

Table 10

The findings of linear regression analysis: supporting factor as dependent variable $(n=468)$

Coefficient

\begin{tabular}{|c|c|c|c|c|c|c|c|}
\hline \multirow[b]{2}{*}{ Model } & \multicolumn{2}{|c|}{$\begin{array}{l}\text { Unstandardized } \\
\text { Coefficients }\end{array}$} & \multirow{2}{*}{$\begin{array}{l}\text { Standardized } \\
\text { Coefficients } \\
\text { Beta }\end{array}$} & \multirow[b]{2}{*}{$\mathbf{t}$} & \multirow[b]{2}{*}{ Sig. } & \multicolumn{2}{|c|}{ Collinearity Statistics } \\
\hline & $\bar{B}$ & Std. Error & & & & Tolerance & VIF \\
\hline 1 (Constant) & 37.889 & .907 & & 41.788 & .000 & & \\
\hline $\begin{array}{l}\text { Knowledge of } \\
\text { students }\end{array}$ & $-.149(a)$ & $.026\left(\mathrm{~s}_{\mathrm{a}}\right)$ & -.255 & -5.699 & .000 & 1.000 & 1.000 \\
\hline
\end{tabular}

a. Dependent Variable: Supporting factors

The raw regression coefficient $(a)$ which is in the column labelled ' $\mathrm{B}$ ' under the heading 'unstandardized coefficients' for the association between students' knowledge about NPM (the IV) and their impression towards supporting factors (the mediator) is -.15 and the standard error for this raw regression coefficient $\left(s_{a}\right)$ which is labelled as 'Std. Error' is .03. The following table is the regression analysis with knowledge and attitude predicting practice. 
Table 11

The findings of linear regression analysis: practice as dependent variable $(n=468)$

Coefficient

\begin{tabular}{|c|c|c|c|c|c|c|c|c|}
\hline \multirow{2}{*}{\multicolumn{2}{|c|}{ Model }} & \multicolumn{2}{|c|}{$\begin{array}{l}\text { Unstandardized } \\
\text { Coefficients }\end{array}$} & \multirow{2}{*}{$\begin{array}{l}\text { Standardized } \\
\text { Coefficients } \\
\text { Beta }\end{array}$} & \multirow[b]{2}{*}{$\mathbf{t}$} & \multirow[b]{2}{*}{ Sig. } & \multicolumn{2}{|c|}{ Collinearity Statistics } \\
\hline & & $\overline{\mathbf{B}}$ & Std. Error & & & & Tolerance & VIF \\
\hline \multirow[t]{3}{*}{1} & (Constant) & 35.431 & 2.761 & & 12.834 & .000 & & \\
\hline & $\begin{array}{l}\text { Knowledge of } \\
\text { students }\end{array}$ & .149 & .038 & .173 & 3.933 & .000 & .935 & 1.070 \\
\hline & Supporting factors & $.608(b)$ & $.065(\mathrm{sb})$ & .412 & 9.390 & .000 & .935 & 1.070 \\
\hline
\end{tabular}

Note: a. Dependent Variable: Practice of students

The raw regression coefficient for the association between the students' impression towards supporting factors $(b)$ and practice of NPM (controlling for students' knowledge about NPM) is .61; the standard error for this regression coefficient $\left(s_{b}\right)$ is .07 . The researcher goes to the webpage for the Sobel's test and find the portion of the page provided to enter these values to complete the analysis and the results are as follow:

Table 12

The findings of Sobel Test Mediation Analysis ( $n=468)$

\begin{tabular}{lllccl}
\hline Input & & & Test statistic & Std.Error & p-value \\
\hline $\mathrm{a}$ & -.15 & Sobel test & -4.33683384 & 0.02109834 & 0.00001445 \\
$\mathrm{~b}$ & .61 & Aroian test & -4.31550966 & 0.02120259 & 0.00001592 \\
$\mathrm{sa}$ & .03 & Goodman test & -4.35847729 & 0.02099357 & 0.0000131 \\
$\mathrm{sb}$ & .07 & & (Preacher, K.J., 2010-2016) & \\
\hline
\end{tabular}

The test statistic for the Sobel test is -4.34 , with an associated $p$-value of .000 . The fact that the observed $p$-value is below the established alpha level of .05 indicates that the association between the IV and the DV (in this case, students' knowledge about NPM and their practice of NPM) is significant by the inclusion of the mediator (supporting factors) in the model and there is evidence of an indirect mediation effect.

Conclusively, the findings of mediation analysis in a relationship between the student nurses' knowledge on nursing process and their impression towards their application of nursing process reveals that their attitude does not have any mediation effect while translating the knowledge to practice. Meanwhile, supporting factors is found to be the factor mediating between knowledge to practice as an indirect mediation effect. This indicates that the supporting factors that support the implementation of nursing process application to be more important that the student nurses who were translating their knowledge into their daily practices. 


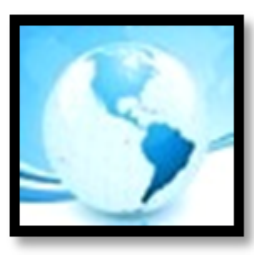

\section{MALAYSIAN ONLINE JOURNAL OF EDUCATIONAL MANAGEMENT (MOJEM)}

\section{DISCUSSION}

This study is evaluating the nursing education agenda from Nursing's Vision 2020 which is laid by the Department of Higher Education, Ministry of Education based on the Vision 2020, Malaysia. The intended target for this agenda is "the inclusion of the Nursing Process Model into nursing practice by 2015, as a basis for building a strong background in critical thinking and problem solving in its effort to provide the highest quality care to clients" and "the fresh nursing graduates are expected to apply NPM in their practice by 2016". This study aims to identify the factors influencing and mediating in application of nursing process.

While identifying the student nurses' demographic characteristics (gender and mode of study), their attitude, and impression towards supporting factors as predictors to their practice, the different gender and mode of study did not significantly predict nor impact the practice of the nursing process. However, knowledge, attitude and impression towards supporting factors significantly predict and impact the student nurses' practice of nursing process. It indicates that despite the gender of the nurses, their qualification of either studying diploma or bachelor or master or PhD, they are practicing the nursing process. However, the student nurses' knowledge, attitude and impression towards supporting factors are significant predictors. It indicates that their knowledge, attitude and supporting factors do influence their nursing practice process.

Concerning the attitude and supporting factors as the mediating factors between knowledge to practice, the result reveals that 'attitude' as a mediator has not been met at the bivariate level. However, supporting factors significantly predict the relationship between knowledge and practice through showing an indirect mediation effect. It indicates that the attitude does not mediate while translating knowledge to practice, whereas supporting factors are found to be indirectly influencing application of the nursing process. It shows that the factors that support on implementation of nursing process application are the important concern while the student nurses are practicing their knowledge into their daily practices.

The study conducted by Aseratie, Murugan and Molla (2014), revealed that nurses who had high knowledgeable level were $27 \%$ times more likely to carry out the nursing process than low knowledge level group nurses. It indicates knowledge to be an important aspect in carrying out practice. The study conducted by Afolayan et al. (2013) identified that the challenges in the lack of nursing application was due to inadequate practical knowledge, inadequate staffing, over workload, and inability to provide the needed materials from management. To overcome these issues and challenges, the researchers recommended that the Nursing and Midwifery Council should embark on seminars regularly, workshops and symposia which focused on practical implementation of nursing process.

A study conducted in the UK by Hale et al. (1997), and Davis et al. (1994) showed that the analysed nursing records were not providing a sufficient figure of patients' needs whilst implementing nursing care (cited by Pokorski et al., 2009). Reppetto and Sauza (2005) investigated the steps of the nursing process implemented as a routine in a university hospital. Their study showed that all steps were performed and yet, there were problems in formulating nursing diagnosis and matters such as recording the patient's history and nursing implementation prescriptions, and evaluation of the expected results were not recorded adequately (cited by Pokorski et al., 2009). Lima and Kurgant's (2006) published study also mentioned that it has difficulties in developing the nursing process for all stages with Kurgrant suggesting that there should be a changes in terms of increasing the working process and speeding up the quality of actions in education and providing care (cited by Pokorski and et al., 2009).

At present, nursing process application in Brazil, USA and Canada has developed tools which allows computerization in the implementation of nursing process application. Similarly, the three studies conducted by Lucena and Barros (2006), Lunney, (2006), and Sperandio and Evora (2005) suggested that electronic records may provide a significant input in the implementation of the nursing process successfully (cited by Pokorski et al, 2009). 


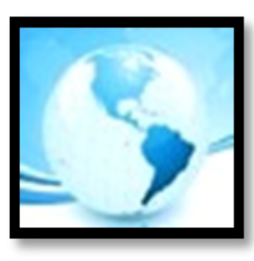

\section{MALAYSIAN ONLINE JOURNAL OF EDUCATIONAL MANAGEMENT (MOJEM)}

As mentioned by Pokorski et al. (2009), the implementation of nursing process program should mean the need to train, improve and update the nurses. By doing so, the knowledge can be implemented to the nurses immediately. In addition, Hermida and Araujo (2006) indicated that there should be knowledge on the institutional structure, on the institution's demands and facilities' basic requirements while starting the systematization of the nursing process (cited by Mahmoud \& Bayoumy, 2014).

The issues related with the NPM implementation is concerning the factors that influences any change process. Introducing any new context create issues such as adjustment, instability in using it, and trial and errors. In the nursing education and practice arena, the nursing process was introduced to be applied in the nursing education and practice because of its beneficial factors such as helping the nursing care becoming more transparent, showing more evidence as a legal aspect, providing clearer descriptions of the client's care and health status, and expressing the evidence of decision-making. However, its implementation raises many issues such as lack of actual application due to inadequate practical knowledge on the nursing process, staffing, overwork load, and inadequate needed materials from management. Therefore, most of the studies suggested conducting education program, training, seminars, workshops and symposiums regularly on that. Furthermore, one study highlighted that having electronic records can help in allowing for a more successful implementation of the nursing process.

This result reveals that the hospital administration support, the resources needed, the time to apply, optimal nurse patient ratio, appreciation feedback as a motivation, effective monitorization and evaluation the application of nursing process, a supportive hospital learning environment, improvements on the staff nurses' application of nursing process and the student nurses' confidence to apply nursing process in real practical settings are all the variety of aspects needed to focus for the student nurses' application of nursing process in Malaysian Nursing Education context to grasp the intended target of Department of Higher Education.

\section{IMPLICATIONS OF THE FINDINGS}

Based on the findings, the implications on the implementation of nursing process application in Malaysian nursing context are: 1) Education and training programmes concerning nursing process with special attention to increasing nurses' knowledge and improving the attitudes while developing more skills for all levels of nurses are needed; 2) Improving and upgrading the application of nursing process in both teaching and clinical setting harmoniously in order to reduce theory practice gap 3) Motivating the academic staff and student nurses including all levels of nurses in clinical setting which would further promote consistency in the nursing process; 4) Paying more attention on effective monitoring and evaluation system in both teaching and clinical settings; 5) Creating a favourable working/learning climate through adequate staffing and resources; 6) Improving the recognition and collaboration amongst the nurses as well as with other health care professionals.

It would be an honour if the results of this study help to contribute the important highlights for the education policy makers and health care planners to outlook the feasibility of the model in the Malaysian nursing context and its implementation process. Furthermore, the results of this study can be referred as a baseline data for future related studies in Malaysian nursing context and other countries' nursing context as well.

\section{CONCLUSION}

The process of successful implementation of education policy is dependent on how those policies are implemented effectively. The achievement of the plan depends not only on effective implementation but also prompt monitoring and evaluation system. Hoy and Miskel (1978, p.215) stated that policies are not only formulated but also it needed to be programmed, communicated, monitored and evaluated (cited by Okoroma, 2006). 
In the implementation of nursing education and practice policy in Malaysian nursing context, effective monitoring and evaluation system is needed to identify whether the implementing agenda and strategies are met with the intended target. To trace the achievement of the implementing public policy and agenda, the policy makers and strategic planners need to conduct surveys, audits, and to monitor and evaluate critically before, during and after the implementation process. In addition, implementing the NPM application especially in real clinical context requires supporting the needed resources from management and creating a balanced nurse patient ratio. The learning process of student nurses should reflect the climate and culture of a real clinical setting in order for them to practice becoming future professional practice nurses.

The important role of strategic planner/policy makers in the implementation of education policy includes designing the policy which is relevant with the existing conditions. Currently, the nurse patient ratio in Malaysian health care system is unbalanced. Based on the findings of quantitative and qualitative reveals that the supporting factors (hospital administration support, adequate resources to apply nursing process, sufficient allocated time, optimal nurse patient ratio, appreciative feedback, monitoring and evaluation, applying nursing process in real setting and proper training program) is mediating while applying nursing process. The current statistic confirmed the imbalance ratio of nurse patient and their heavy workload. Therefore, the policy makers and health care planners should also plan to improve the nurse patient ratio, be it nurses with a Degree and or Diploma in order to upgrade the status of nursing in Malaysia.

The findings of an evaluation study by the Malaysia's Department of Higher Education revealed that the influencing factors upon application of nursing process are; the student nurses' knowledge, attitude and supporting factors. Among these three factors, the supporting factor is mediating in translation of knowledge to practice of student nurses. There are five types of barriers that are influencing change, namely, awareness and knowledge, motivation, acceptance and beliefs, skills, and practicability. Awareness and knowledge are the vital first step in enabling change to occur. The evidence shows that the health care professionals are often not aware of the latest evidence-based guidance and lack of familiarity with it. Therefore, because of the constraints in supporting factors, it cannot expect a complete success amongst these barriers. However, when the imbalance become balanced, the policy can be implement more effectively.

\section{REFERENCES}

Afolayan, J. A., Donald, B., Baldwin, D.M., Onasoga, O. \& Babafemi, A. (2013). Evaluation of the utilization of nursing process and patient outcome in psychiatric nursing: Case study of psychiatric Hospital Rumuigbo, Port Harcourt. Advances in Applied Science Research, 4(5), 34-43. Retrieved from: http://www.imedpub.com/articles/evaluation-of-the-utilization-of-nursing-process-and-patientoutcomein-psychiatric-nursing-case-study-of-psychiatric-hospitalrumui.pdf

Alfaro-Lefevre R. (2006). Nursing Process Overview. In: Kogut H, editor. Applying Nursing Process( $6^{\text {th }}$ ed. ) Philadelphia: Lippincott Williams \& Wilkins, p. 4-41.

Aseratie, M., Murugan, R. \& Molla, M. (2014). Assessment of Factors Affecting Implementation of Nursing Process Among Nurses in Selected Governmental Hospitals, Addis Ababa, Ethiopia; Cross Sectional Study. J Nurs Care, 3(3), 1-8. Retrieved from: http://dx.doi.org/10.4172/2167-1168.1000170

Creswell, J. W. (2012). Educational Research: Planning, Conducting, and Evaluating Quantitative and Qualitative Research(4 ${ }^{\text {th }}$ ed.). Pearson Education, Inc. 


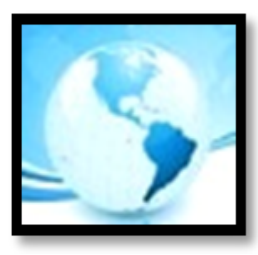

Cunha, S.M.B. \& Barros, A.L.B.L. (2005). Análise da implementação da Sistematização da Assistência de Enfermagem, segundo o Modelo Conceitual de Horta. Rev Bras Enferm, 58(5), 568-572.

Dart A. (2013). Reporting Multiple Regressions in APA format - Part one \& two. Retrieved from: http://www.adart.myzen.co.uk/reporting-multiple-regressions-in-apa-format

Davis, B.D., Billings, J.R. \& Ryland, R.K. (1994). Evaluation of nursing process documentation. Journal of Advanced Nursing, 19(5), 960-968.

De la Cuesta, C. (1983) .The nursing process: from development to implementation. Journal of Advanced Nursing, $8(5), 365-371$.

Ehrenberg, A., Ehnfors, M. \& Thorell-Ekstrand I. (1996). Nursing documentation in patient records: experience of the use of the VIPS model. Journal of Advanced Nursing, 24(4), 853-867.

Farmer, E. (1986) On introducing a systematic method for the practice and study of nursing in two clinical areas in Scotland: a retrospective analysis of the change process. Unpublished PhD. University of Edinburgh.

Foroozan, A.S. \& Tahereh, A. (2011). Factors Influencing Implementation of Nursing Process by Nurses: A Qualitative Study. Knowledge and Health, 6 (3),16-23. Retrieved from: http://en.journals.sid.ir/ViewPaper.aspx?ID=252503

Ghasemi, A. \& Zahediasl, S. (2012). Normality Tests for Statistical Analysis: A Guide for Non-Statisticians. International Journal of Endocrinology Metabolism, 10 (2), 486-489. Retrieved from: http://dx.doi.org/10.5812/ijem.3505

Hagos, F., Alemseged, F., Balcha, F., Berhe, S. \&Aregay, A. (2014). Application of Nursing Process and Its Affecting Factors among Nurses Working in Mekelle Zone Hospitals, Northern Ethiopia. Nursing Research and Practice, 2014, 1-8. Retrieved from: http://dx.doi.org/10.1155/2014/675212

Hale, C.A, Thomas, L.H., Bond, S. \& Todd, C. (1997). The nursing record as a research tool to identify nursing interventions. Journal of Clinical Nursing, 6(3), 207-14.

Hermida, P.M.V. \& Araújo, I.E.M. (2006). Sistematização da assistência de enfermagem: subsídios para implantação. Rev Bras Enfermagem, 59(5), 675-679.

Hoy, W.K. \& Miskel, C.G. (1978). Educational administration: theory, research, and practice, New York: Random House.

Lima, A.F.C. \& Kurcgant, P. O. (2006). processo de implementação do diagnóstico de enfermagem no Hospital Universitário da Universidade de São Paulo. Rev Esc Enfermagem USP, 40(1),111-116.

Lucena, A. F. \& Barros, A.L.B.L. (2006). Nursing diagnoses in a brazilian intensive care unit. Int J Nurs Terminol Classif, 17(3), 139-146.

Lunney, M. (2006). Helping nurses use NANDA, NOC and NIC. Novice to expert. J Nurs Adm, 36(3), $118-125$. 


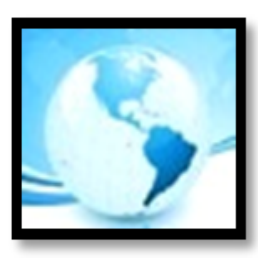

Mahmoud, M.H. \& Bayoumy, H.M. (2014). Barriers and Facilitators for Execution of Nursing Process from Nurses' Perspectives. International Journal of Advanced Research, 2 (2), 300-315. Retrieved from http://onlinelibrary.wiley.com/doi/10.1046/j.1365-2648.1997.00472.x/epdf

Martin, E., Garcia, F., \& Asenjo, E. (1997) Diagnösticos de enfermeria. Estrategia de implantaciön. Revista Rol de Enfermeria, 225 (mayo), 57-63.

Mason, G.M.C. \& Attree, M. (1997). The relationship between research and the nursing process in clinical practice. Journal of Advanced Nursing, 26 (5), 1045-1049. Retrieved from: http://onlinelibrary.wiley.com/doi/10.1046/j.1365-2648.1997.00472.x/epdf

Mellanova. A. (2005). The nursing process in the Czech Republic. In: Habermann M, Uys LR, editors. The Nursing Process: A Global Concept. $1^{\text {st }}$ ed. Edinburgh: Elsevier Churchill Livingstone( pp. 98-120).

Miller, J., Steele, K., \& Boisen, A. (1987) The impact of nursing diagnosis in a long-term care setting. Nursing Clinics of North America, 22 (4), 905-915.

Ministry of Higher Education Malaysia (2010). Development of Nursing Education in Malaysia: Towards the Year 2020, Department of Higher Education: Ministry of Higher Education Malaysia. Retrieved from: http://www.moe.gov.my/images/Terbitan/Rujukan-

Akademik/Development\%20of\%20Nursing\%20Education\%20in\%20Malaysia\%20Towards\%20the\%20Year \%202020.pdf

NICE (2007). How to Change Practice. National Institute for Health and Clinical Excellence: London. Retrieved from: https://www.nice.org.uk/media/default/about/what-we-do/into-practice/support-for-serviceimprovement-and-audit/how-to-change-practice-barriers-to-change.pdf

Okoroma, N. S. (2006). Educational policies and problems of implementation in Nigeria. Australian Journal of Adult Learning, 46 (2), 244-263. Retrieved from: http://files.eric.ed.gov/fulltext/EJ797605.pdf

Specht, J \& Drey, K. (1987). The implementation of nursing diagnoses: the lowa Veterans Home experience. Nursing Clinics of North America, 22 (4), 917-933.

Sperandio, D.J. \& Évora, Y.D.M. (2005). Planejamento da assistência de enfermagem: proposta de um softwareprotótipo. Rev Latino- am Enfermagem, 13(6), 937-943.

Pokorski, S., Moraes, M.A., Chiarelli, R., Costanzi, A.P. \& Rabelo, E.R. (2009). Nursing Process: From Literature to Practice. What are we actually doing? Rev Latino-am Enfermagem 2009 maio-junho, 17(3),302-307 Retrieved from: http://dx.doi.org/10.1590/S0104-11692009000300004

Preacher, J.K. \& Leonardelli, G. J. (2010-2016) Calculation for the Sobel test: An interactive calculation tool for mediation tests. Retrieved from: http://quantpsy.org/sobel/sobel.htm

Salcedo, Z.A. (2004). Implementing the nursing process in a teaching hospital ward: an action research study. PhD thesis, University of Glasgow. Retrieved from: http://theses.gla.ac.uk/3718/1/2004ZaragozaPhD.pdf

Seaback, W.W. (2006). Nursing Process: Concepts and Applications(2 ${ }^{\text {nd }}$ ed), Clifton Park, N.Y. : Thomson Delmar Learning. 
Serrano, R., Saracibar, I., Diaz, T., Tina, P., \& Narvaiza, MJ. (1994) Donde comienza la calidad cientifica de los documentos de enfermeria? Revista Rol de Enfermeria, (191-192), 33-40.

Uys, L. \& Habermann, M. (2005). The Nursing Process: A Global Concept (1st Ed), Edinburgh : Elsevier Churchill Livingstone. Retrieved

from: https://books.google.com.my/books?id=szVjtbGNDYcC\&pg=PA119\&lpg=PA119\&dq=0\%E2\%80\%99Connel I+study+about+nursing+process\&source\#v=onepage \&q=0\%E2\%80\%99Connell\%20study\%20about\%20nur sing\%20process\&f=false

Vaz, A.F., Macedo, D.D., Montagnoli, E.T.L., Lopes, M.H.B.M. \& Grion, R.C. (2002). Implementação do processo de enfermagem em uma unidade de radioterapia: elaboração de um instrumento para registro. Rev Latinoam Enfermagem,10(3), 288-297.

Walton, I. (1986) The Nursing Process in Perspective: A literature Review. University of York. Department of Social Policy and Social work.

Willis, A. (2012). Professional Nursing Topics - Reviewing the Nursing Process. Retrieved from: http://www.ausmed.com.au/online/professional-nursing-topics-reviewing-the-nursing-process-video1599035

Yildirim, B. \&Ozkahraman, S. (2011). Critical Thinking in Nursing Process and Education.International Journal of Humanities and Social Science, 1 (13), 257-262. Retrieved from: https://www.ijhssnet.com/journals/Vol_1_No_13_Special_Issue_September_2011/34.pdf 